\title{
Den levende vekselvirkning \\ Kropskulturens gammelnordiske historie og idrættens aktuelle forandring
}

\author{
af Henning Eichberg
}

Historievidenskab skrider ikke automatisk frem udelukkende efter en indre logik eller efter et naturligt akkumulations- og vækstprincip. Den bevæger sig derimod som enhver anden videnskab i spring - fra et paradigme til et andet. Der sker strukturelle brud og blitzagtige opdagelser, der vælter ældre normalvidenskabelige systemer, opbygget af generationer af forskere (Kuhn 1962).

Sådanne paradigmespring sker aldrig uafhængigt af samfundet, af videnskabens hverdagskulturelle miljø. Vi kender kun lidt til samfundets påvirkning, men vi kan regne med eller håbe, at en levende vekselvirkning mellem videnskaben og ikke-videnskabelige folkelige miljøer $\mathrm{i}$ højere grad fremmer videnskabens forandring og tilpasning end en kunstig akademisk isolation.

Det er her, en idrætshistorisk forening kan få betydning. Kan en folkelig vekselvirkning give eksperterne nye ideer?

Historiografien om det gamle Nordens idræt og kropskultur kan ses som et eksempel på forskningens socio-kulturelle relativitet.

\section{Yoga i det gamle Norden? - „Useriøse “ spørgsmål}

Efter et indledende forsøg i 1801 af Engelstoft, der ikke blev fulgt op, blev der først omkring 1900 etableret en gennemgående forskningstradition omkring idræt i det gamle Norden (Bjarnason 1905; Götlind 1923; Lukas 1969, s. 38-44; Svahn 1970; Wahlqvist 1979; Wischmann/Svahn 1980; Ueberhorst 1980, s. 26-46). Denne tradition har formidlet et meget entydigt billede af oldskandinavisk idræt: konkurrenceformer med udspring i krigerisk kamp, hårde kraft-konfrontationer mand og mand imellem, boldspil og brydning, væddeløb og spring som forløbere for den moderne sport; det gamle Norden - hævdedes det - udviklede „,konkurrencesport" med „,træning“"og ,rekorder", med ,,professionalisme" og ,,sportsjournalister".

På denne måde kunne man genkende sig selv i historien. Der var identitet gennem kontinuitet $i$ historien. I grunden stillede historien ingen spørgsmål udover dette: hvordan har det virkelig været? Der var ingen problematik i 
historien, kun fakticitet.

Nordens gamle idræt som sportens spejl? - Det skabte ikke kun et problem for historiografiens funktion. (Fordi: hvis der ikke er noget anderledes at opdage i historien, så er historiografien i grunden overflødig. Vi ved jo alt $\mathrm{i}$ forvejen). Det rejser også indholdsmæssige spørgsmål, for vi kan høre røster, der siger: Der fandtes også yoga i det gamle Norden.

„Debatten om ordets og tankens kraft - mantra og suggestion - er ikke et specielt asiatisk fænomen. I Norden har vi kilder, der vidner om et dybtgående kendskab til disse midler og deres virkning. (...) I de nordiske folkeviser har vi runekunsten - lyde der har været kendt og brugt som de indiske mantras. I de islandske håndskrifter, i Eddaen, står bl.a. at Odin blandt guderne kaldes Ome. Ordet OM betyder lyd på oldnordisk (omr) og på Sanskrit. Fra den indiske tradition ved vi, at det er symbolet på den inderste oprindelige lyd eller vibration." (Saraswati 1975, s. 5-6).

Man kan indvende flere ting imod en sådan udtalelse. Fra den positivistiske videnskabs side kan man godt tvivle på, om selve kildefortolkningen er rimelig og svarer til etablerede filologiske metoder. Men også set fra et mere relativistisk videnskabssyn kan man nære skepsis over for tendensen til at blande kilder og elementer fra forskellige kulturer sammen uden rimelige differentieringer - det være sig indiske, skandinaviske, indianske, ægyptiske etc. Viser der sig ikke her snarere en tanketradition fra ,,californisk synkretisme" end en nordisk historieopfattelse?

Men hvor seriøs eller useriøs man end vil opfatte røster fra det nyspirituelle miljø: de henviser til nogle kilder og materialer, der er blevet overset af den konventionelle idrætsforskning, og som snarere burde tages alvorligt. På det arkæologiske plan kan nævnes (Bindu 16/1976, s. 2, 5, 29; også Fischer 1963):

- To menneskefigurer af bronze med emaille er beslag på en spand, der blev fundet i Osebergskibet i Norge, sandsynligvis af keltisk oprindelse (Irland?), fra det 8.-10. århundrede. Disse figurer sidder $\mathrm{i}$ lotusstillingen; derfor kaldes spanden også ,,buddhabøtten“" (Brøgger 1928, s. 71-80).

- En bronzefigur fra Fangel, fra bronzetiden, sidder i diamantstillingen og holder øjnene lukkede.

- En dansk bronzestatue fra Grevens vænge på Sjælland fra 900-700 før vor tidsregning ,,går i bro“. Stillingen kaldes i yoga også ,,hjulet“.

Udover det er der rejst spørgsmål om en nytolkning af nogle fænomener, der allerede er kendte fra de skriftlige kilder: 
- Runekunsten: har det måske været mere end en skrivekunst, nemlig en gren i kropskulturen, en integration af ord, lyd, tegn, bevægelse, musik og farve, en ,nordisk mantravidenskab"? (Bindu 12, 1974).

- Udesidning, der er dokumenteret $\mathrm{i}$ islandske sagaer som en form for tryllekunst eller profetisk teknik: har det været en sprituel kropsøvelse, som kan sammenlignes med naturmeditation og visionsfremkaldelse $i$ indianerkulturer? (Gimle 1982-83).

- Odins selvofre $\mathrm{i}$ verdenstræet Yggdrasil sådan som det er beskrevet $\mathrm{i}$ Eddaens Havamal: er det udtryk for en shamanisk indvielsesritus? (Erikson 1982, Nielsen 1983).

\section{Dans, meditation og ekstase - videnskabens seriøse svar}

Hvis man tager disse nytolkninger alvorlige, skønt de er udsprunget af et ikke-videnskabeligt og måske ,useriøst“ miljø, så kan man opleve en række overraskelser. Det viser sig nemlig, at den nordiske filologi og historiografi allerede længe har beskæftiget sig med tilsvarende aspekter.

En del forskning har været rettet mod det gammelnordiske trolddomsvæsen. Allerede $\mathrm{i}$ det forrige århundrede blev man opmærksom på visse forbindelser mellem nordisk-skandinavisk og samisk trolddomspraksis (Fritzner 1877). Men det er først siden 1930'rne, at der findes en gennemgående diskussion om sejd-fænomener og deres sammenhæng med shamanisme (Strömbäck 1935; Jaide 1937; Vries 1956-57 II, s. 27-106; Ström 1961, s. 77-82; Buchholz 1968; Closs 1968; Davidson 1973; Doht 1975; Höfler 1976; Duerr 1982. Kritik hos Fleck 1971. En anderledes fortolkning i tilknytning til Dumézil: Dillmann 1982).

I sammenhæng med denne trolddoms-, sejd- og shamanismeforskning er især tre fænomener af betydning for kropskulturhistorien: dans, meditation og ekstase.

Dansen, der er en central del i mange folks kropskultur, er til dels blevet helt fornægtet for det gamle Nordens vedkommende. I idrætshistorien fra Bjarnason 1905 og indtil $i$ dag levnes der enten slet ingen eller kun en marginal plads for dansen. (En undtagelse var - $i$ sandhedens interesse - et afsnit $i$ den i øvrigt olympisk-sportive bog af Diem 1971 I, s. 521-22). En af de mest anerkendte germanistiske filologer i 20 'rne, Andreas Heusler, skrev i 1924: "Det er en kendsgerning af første rang, at den nordiske oldtid ikke dansede." Selskabsdans på Island er bare opstået som følge af import sydfra siden 1100. I øvrigt og supplerende: „Scandinavia non cantat“" (se Wolfram 1936, s. 181). 
Sådan har man ikke altid set på det. Da Engelstoft i 1801 påbegyndte hele forskningstraditionen om idræt i det gamle Norden, var hans næststørste kapitel om dansen (det største var om svømning).

Heller ikke de nyere undersøgelser vil acceptere den ældre tese om dansens fravær eller udskillelse fra den gammel-skandinaviske kropskultur. Det er rigtigt, at de skriftlige kilder og i særdeleshed sagaerne er meget sparsomme, hvor det drejer sig om dans, men der findes dog tilstrækkelige skriftlige henvisninger til at tillade danserekonstruktioner, især fra folkelivsforskningens side (Wolfram 1936, s. 181-97, også Meschke 1931; GrünerNielsen 1933; Stumpf 1936; Adamson 1957). Sværddans, som Tacitus og senere Olavs Magnus har berettet om, har været et prioriteret forskningsfelt og integrerer netop dansens og kampidrættens elementer (Mayer 1899; Norlind 1911; Sharp 1911). Men vi kender også til hedenske kultdanse i templer i Uppsala og om langvarige forbudskampe fra den kristelige kirke imod hedenske dansevaner. I den hedenske fest var dansen og ,idræt" (forstået i sin moderne indsnævrede betydning) netop ikke adskilt fra hinanden.

Udover de skriftlige kilder er det først og fremmest arkæologiske kilder, der kan danne grundlag for nye undersøgelser af dansen:

- Guldgubber er små guldplader (der findes flere end hundrede), som er dateret til det 5.-10. århundrede. De viser enkeltskikkelser eller par, der på grund af deres bøjede knæ antages at være dansere, - amuletter fra en danse- og frugtbarhedskult, måske i tilknytning til guden Frey? (Máckeprang 1943; Holmqvist 1960; Hölscher 1982).

- Labyrinter, som der er registreret mere end 500 af over hele Norden, har efter den nyeste opfattelse deres oprindelse i danseformer (,,jomfrudans"). Herfra udvikledes de til dansepladser i form af stensætninger eller græslabyrinter (,,trøjborg", ,trelleborg", ,troy town") og senere til ornamenter og bygninger (Matthews 1922; Mehl 1956 og 1972; Vries 1957; Kern 1982).

- Som fremstilling af dans eller en anden kropsøvelse kan også nogle pynteskiver forstås, der viser parvis sammenflettede mennesker, der ligger over kors (Oxenstierna 1956, s. 47-50, ill. 81-97).

Disse arkæologiske dansebilleder kan åbne øjnene for andre dansere $\mathrm{i}$ sammenhænge, som kan findes på helleristninger og på hjelmplader, på brakteater og - uafhængigt af de kontroverse fortolkninger - på guldhornene fra Gallehus (Ringbom 1949; Oxenstierna 1956; Hartner 1969). 
Meditation som kropsøvelse kan også først og fremmest bearbejdes på grundlag af arkæologiske kilder. Udover de nævnte fire bronzefigurer er der flere andre, der burde fortolkes i denne sammenhæng:

- En svensk bronzefigur fra det 11. århundrede sidder i lotusstilling (?). På grund af dens store phallos betegner man statuen som et billede af frugtbarhedsguden Frey (Magnusson 1978, s. 75).

- En bronzepynteskive fra folkevandringstiden, fundet i Ingersheim, viser en menneskeskikkelse $i$ en meditationsagtig stilling (Neckel 1939, s. 108). (Fig. 1).

- Man har også i Sverige fundet en Buddha-figur fra Nordindien. Den stammer fra folkevandringstiden (Magnusson 1978, s. 19). Det henviser til mulige tidlige kontakter med østlige kropskulturformer.

Sådanne kilder kan bidrage til en nyvurdering af de litterære kilder, der fortæller om udesidning og stenmeditation som metoder til at fremkalde fremtidsvisioner. Af særlig interesse kunne det være nærmere at undersøge ,,sejdhjällen", den nordiske troldmands sæde eller stativ, som man har sammenlignet med kongens trone, med shamanens sæde blandt sibirfolk og med træfodstativet i det delphiske orakel (Strömbäck 1935, s. 110-18).
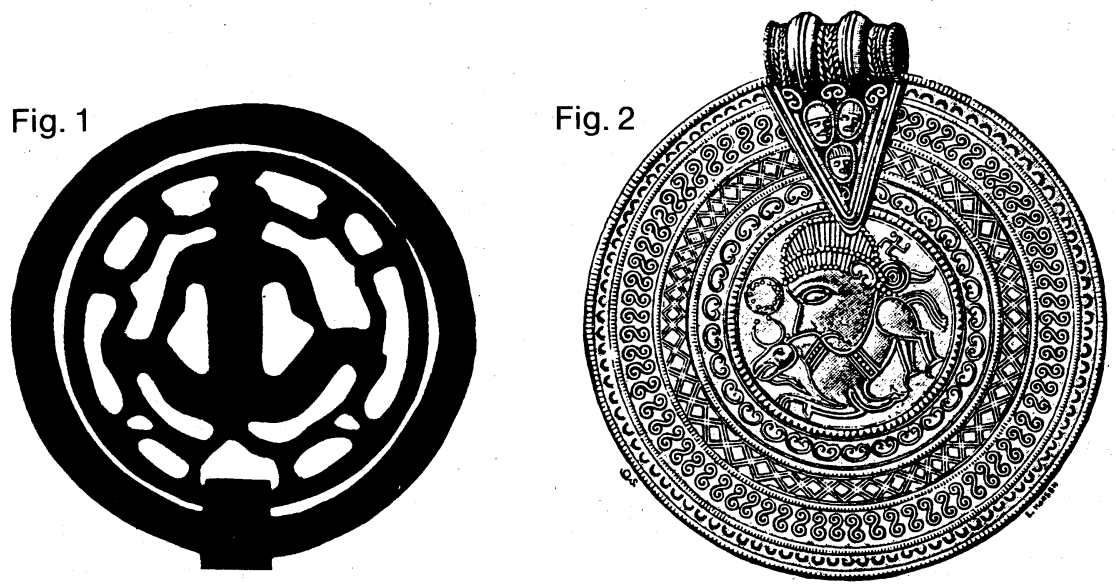

Fig. 1. Bronzepynteskive fra Ingersheim, folkevandringstid. „,Primitive Menschendarstellung " - eller nordisk meditationsstilling (udesidning)? Neckel 1939, side 108.

Fig. 2. Brakteat fra Østergotland. „Darstellung des über die Finsternis (Mondkuh) siegenden Sonnengottes. (Hakenkreuz)" - eller shamanisk helbredelse? Neckel 1939, side 159. 
Ekstaseformer er i den gammelnordiske kultur først og fremmest blevet beskrevet i sammenhæng med Odin som shamangud, med bersærkervæsenet, og med trolddom henholdsvis helbredelse. Brakteaterne, d.v.s. guldamuletter fra det 5.-6. århundrede, er her blevet inddraget som kildemateriale.

- En brakteat fra Års (nu i København) viser en danser med hjelm, økse, kølle og spyd. Den tolkes som shamangud (Odin), bl.a. på grund af dens dyrehale (Hauck 1978, s. 397).

- På en hjelmplade fra det 6 . århundrede danser to krigere, en af dem med dyremaske på. Det kan være en henvisning til bersærker, som gud Odins ekstatiske krigere (Magnusson 1978, s. 109).

- En stor del af brakteaterne (fig. 2) er variationer over et bestemt billedtema: Et hoved, der er markeret med åndedrætspile ved mund og næse, bøjer sig over et dyr, som han blæser $\mathrm{i}$ øret. Man har fortolket det $\mathrm{i}$ sammenhæng med det hedenske tryllevers fra Merseburg, der beskriver en helbredelse af en hest. Det var ikke kun en aktivitet på livets kant: Husdyrenes held og helbred stod i centrum af den nordiske kult, siger Grønbech (1939 II, s. 198) Og at åndedrættet var et shamanisk-ekstatisk træk bekræftes gennem fugle, som ledsager ,,healeren“" på næsten alle brakteatre af denne type: shamanens hjælpeånder, Odins ravne?

Også i dette tilfælde illustrerer de arkæologiske kilder, hvad den nyere filologiske forskning har fundet $\mathrm{i}$ de skriftlige beretninger: Der fandtes stærke shamanisk-ekstatiske elementer i det gamle Norden (Buchholz 1968). Det eneste, der manglede, var imidlertid shamanens hovedredskab: trommen. (Det er præcis det, der kan have en betydning for en karakteristik af kropskulturen).

\section{Samfundets sportificering og historiografiens reduktion}

Kilderne viser sig altså i dag så rige og den filologisk-historiografiske litteratur i flere årtier så produktiv på dette felt, at man irriteret kan spørge sig, hvordan idrætshistoriografien har kunnet forbigå disse vigtige emneområder af kropskulturen. Hvorfor skete der en reduktion i forhold til f.eks. Engelstoft, der endnu i 1801 havde øjne for dansen? Hvorfor forsvandt dansen, samtidigt med det gamle idrætsbillede blev formet efter sportens mønster?

Videnskabens selektivitet og ensidighed kan åbenbart ikke bare forstås ud fra sin egen kontekst. Dens mønstre er udtryk for samfundets konfiguratio- 
ner: Samfundets sportificering slår også igennem på historiografiens plan.

Det var derfor heller ikke kun idrætshistorikere, der indsnævrede deres perspektiv. Også kulturhistorikere med et større overblik beskrev en krigerisk-sportslig konfiguration, når de ridsede krops-, bevægelses- eller legekulturens univers op. Heuslers „Scandinavia non saltat" stod ikke alene. Da Wilhelm Grønbech, der ellers stærkt understregede de kultiske og spirituelle elementer i det nordiske samfúnd, ville fremstille lege- og festkulturen, så var der tale om kamp og kappestrid, om sammenligning af mændenes kræfter ved ridning og boldspil, skydning og skænderi. Om dansen er der kun et par bi-bemærkninger, i optællinger ved siden af. Fest - det er mænd, der sidder og drikker øl, brydes og fortæller (Grønbech 1939, s. 153-62, 175-200). Ingen kvinder, ingen dans, ingen ekstatisk bevægelse?

Også DDR-forskningen (Schlette 1972, s. 213-15) fortsætter denne reduktion med andre accenter, hvor kropsøvelser bare udfolder sig mellem hærdning og nytte: Idræt og kropskultur er der, hvor arbejde og krig overlapper hinanden - og ellers intet?

Videnskabens selektivitet er imidlertid ikke kun et produkt af en ensidig tænkemåde. Den går dybere ned, for reduktion må der jo være, men hvad bestemmer selektionens mønstre? Vi tager ikke fejl, hvis vi regner med selektionsprocesser og relativitet i udgangspunktet på sansernes plan. Det er ikke kun ord, der forstås på en selektiv måde, men allerede forskerens blik er relativt.

Det viser arkæologiens blik, for hvilket der dukker nye figurer op udfra et længe kendt materiale. To eksempler kan anskueliggøre dette:

- En brakteat fra Östergotland, der viser det „,klassiske“ mønster - et sygt dyr (en ko?) og healerens hoved med munden ved dyrets øre - blev i 1939 set på en helt anden måde: som fremstilling af ,,solguden (med hagekorset), der sejrer over mørket (måneko)" (Neckel 1939, s. 159). Denne beskrivelse siger ikke kun noget om tidens (1939) opfattelse af svastikasymbolet. Det spejler tillige en karakteristisk kamp- eller konkurrencekonfiguration (der også er sportens): hvor der er to figurer på billedet, så kæmper de mod hinanden - selvfølgelig. Og blikket er kønspolitisk: manden er solen og sejrherre over den kvindelige ko, der er mørket. (Fig. 2).

- Et blik må kastes på en idræt, som blev rekonstrueret i 1939: Vognkonkurrence ved Østersøen i bronzetiden blev dér fremstillet som et hastighedsbillede, der følger den moderne sports konfiguration af klokketid og tidsspænding. Men hvis man ser på de svenske helleristninger, der efter sigende har været model for rekonstruktionen, så opdager man en helt anden konfiguration: ingenting om hastighedsmønster og liniær fremad- 


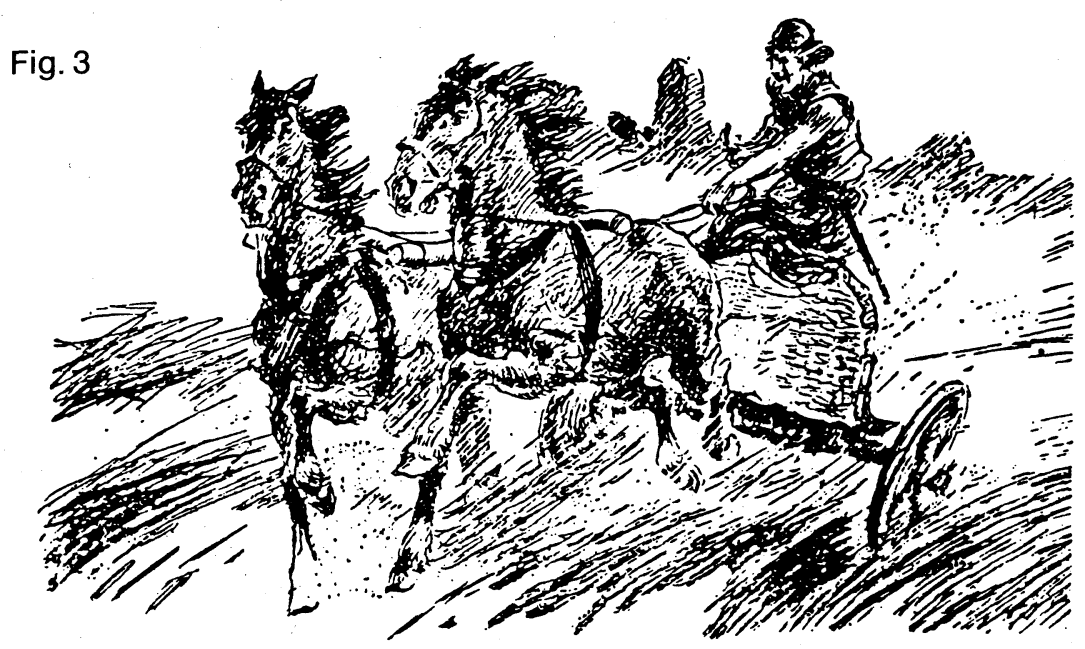

Fig. 3. ,,Væddekørsel ved Østersøen. Rekonstruktionstegning efter svenske helleristninger". Lechler 1939, side 20.

bevægelse (Lechler 1939, s. 20-21). Det var ikke kun et spøgsmål om forskellige fremstillingsteknikker, men det var blikkets og kropsbevægelsens konfigurationer, der står i kontrast til hinanden. (Fig. 3 og 4).

Hvad er konklusionen på et teoretisk plan? Vor videnskabelige forståelse og rekonstruktion bygger altid - altid! - på en særegen kropserfaring, der er samfundsmæssig og relativ. Dette relativerer ikke kun det tidligere historiografiske blik. Også vore egne resultater er under indflydelse af vore nutidige konfigurationer. Det betyder ikke, at forskeren burde være bevidst partisk, men at han burde være en mere sensibel iagttager af sin egen kropshistorie.

Fig. 4

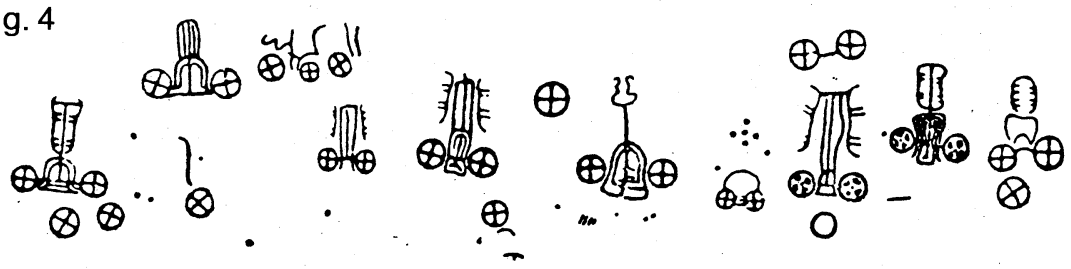

Fig. 4. „,Nordisk væddekørsel, helleristning fra Frännarp i Skåne (Sverige)“. Lechler 1939, side 21. 


\section{Sensationen: trommen er der}

Hvordan en sammenhæng og en levende vekselvirkning med et ikke-akademisk miljø kan skabe nye hypoteser og et nyt blik på kropskulturens kilder, vil jeg anskueliggøre med et sidste eksempel: trommen i det gamle Norden.

Shamanismeforskningen inden for nordisk filologi er, som allerede sagt, nået til det punkt, at der fandtes mange træk i skandinavisk forhistorie, der kan sammenlignes med andre folks shamanisme (samer, sibirfolk, inuitter, indianere). Men der har været en undtagelse: trommen manglede. Og den er netop shamanens hovedinstrument.

Det troede jeg også, og jeg kunne heller ikke ,se“" trommen i oldnordiske arkæologiske kilder, - indtil en højskolelærer gjorde mig opmærksom på noget mærkeligt: Er de skandinaviske helleristninger ikke fulde af dansere med trommen $i$ hånden? Kender vi ikke fra stenalderen såvel som fra bronzetiden masser af figurer, der bærer runde instrumenter, ofte med håndtag som inuittrommen? Nogle figurer er karakteriseret ved phallos eller ved en hale som et dyrs attribut, - også det kan henvise til shamaniske sammenhænge (Broby-Johansen 1979, s. 31, 69, 77, 80). (Fig. 5-8).

Fig. 5

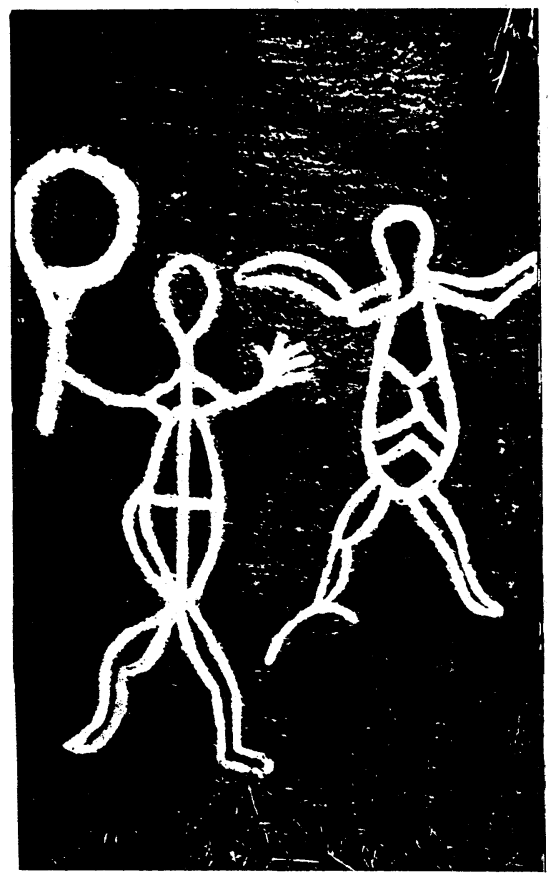

Fig. 6

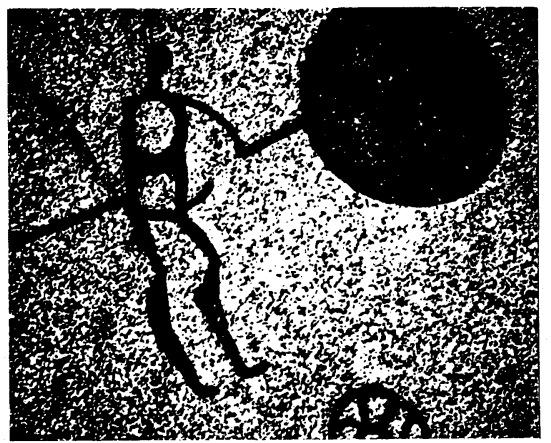

Fig. 5, t.v. Helleristning fra Skavberget, Sør-Kvaløy, Troms.

Fig. 6, øv. Helleristning fra Vitlycke, Tanum, Bohuslen. „En mand med ... solbillede på stolpe“. Broby-Johansen 1979, side 31 og side 69. 
Fig. 7

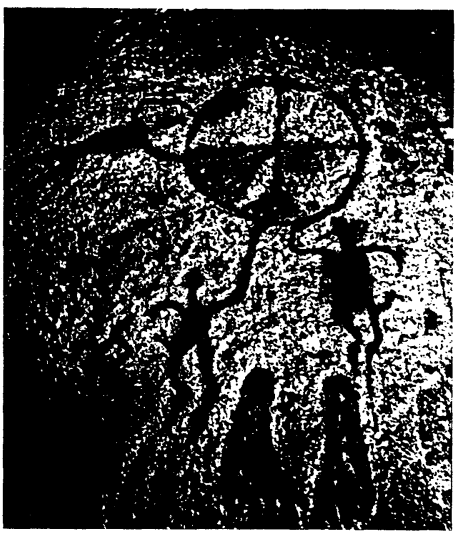

Fig. 8

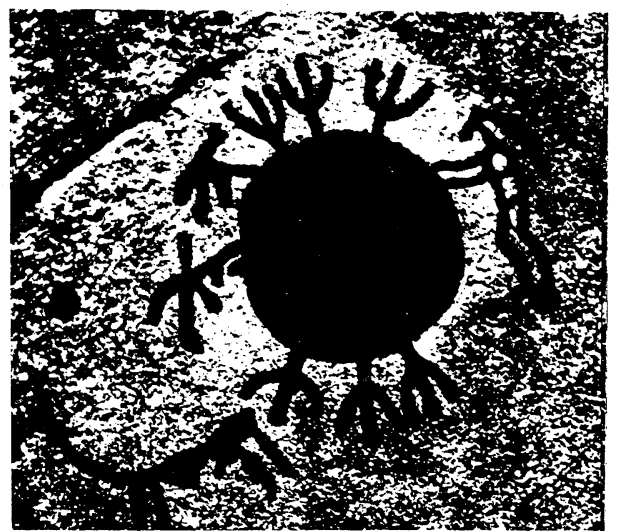

Fig. 7, t.v. Helleristning fra Långemyr, Kalleby, Tanum, Bohuslen. „Mænd med løftet solhjul".

Fig. 8, t.h. Helleristning fra Aspeberget, Tanum, Bohuslen. Broby-Johansen 1979, side 80 og side 77 .

Hvorfor har man indtil i dag ikke „set" disse shamandansere med deres trommer? Fordi de altid blev fortolket som ,"mænd med solbilleder" $i$ analogi til solbilledet på vognen fra Trundholm Mose på Sjælland. Men sådanne solbilleder, som man holder $i$ hånden, er en interpolation og ikke støttet af direkte fund. Korsform, som man fortolker som solhjulets inddeling, findes også som spænding i shamaniske rammetrommer.

Den nye fortolkning bekræftes også af tilsvarende figurer fra inuit-tegninger (Jørgensen 1981, s. 150) og fra helleristninger i Altai-bjergene (Gilberg 1978, s. 7), altså fra klassiske shamaniske kulturer. (Fig. 9 og 10). Derfor har man aldrig set billederne som ,dansere med solhjul", men som shamaner eller trommedansere. (Dermed være ikke sagt, at fortolkningen af korshjulene som solbilleder og som tromme udelukker hinanden). Endelig kan der henvises til en bronzetromme fra Balåkra i Skåne, der dateres til 1500-1300 f.v.t. (Broby-Johansen 1979, s. 77).

Vigtigt i vor metodologiske sammenhæng er, at det nye blik på nordiske trommedansere dukker op $\mathrm{i}$ en tid, da nye shaman- og trommeaktiviteter udbreder sig i vor kultur. Højskolelæreren Kristian Kjær Nielsen, der først gjorde opmærksom på den nye fortolkningsmulighed, fik ikke ideen gennem akademiske bogstudier, men først og fremmest gennem egne udesidningerfaringer og trommeeksperimenter med elever på en mytologisk orienteret dansk folkehøjskole. Kun gennem levende vekselvirkning med andre miljøer 
kan den akademiske forskning opfange sådanne inspirationer.

Hvis hypotesen om de oldnordiske trommedansere bliver bekræftet, så rejser der sig mange yderligere spørgsmål. Trommen bliver hos nogle indianere omskrevet som fugl eller skib, hos samerne som rensdyr eller hest, fordi den er et ,,transportinstrument “ på ekstatiske rejser. Kan det betyde, at nogle skibe på nordiske helleristninger med deres ekstatiske dansere og akrobater kan forstås som ,,skjulte" trommer? Og Odins troldhest Sleipner?

Til trommen hører trommestikker. Samiske og sibiriske trommestikker har ofte form af en hammer (Gilberg 1978, s. 13; Duerr 1983, s. 153). Har måske Tors hammer, der flyver gennem luften, en oprindelse i shamanens redskab? Er denne sammenhæng ikke mere overbevisende end hammeren som våben (der kun findes i Norden i en senere tid, som stridshammer mellem $1450 \mathrm{og}$ 1650 og uden større betydning, Thordeman 1943, s. 127-29). Indeholder Tors rejse i kvindekjole for at hente hammeren tilbage fra jætten Trym måske en henvisning til shamanens seksuelle ambivalens? - Og hvilken forbindelse er der mellem den gammelnordiske tromme og trommen (med fløjten) som heksenes hovedinstrument i senere tider (Göttner-Abendroth 1982, s. 56)?

\section{Et idrætshistorisk paradigmespring?}

Hvad der blandt sådanne hypoteser vil bekræftes gennem fremtidig forskning er åbent. Det er imidlertid på problemstillingens plan, at der aftegner sig et paradigmespring i kropskulturhistorien. Den er ikke længere bare en tilbageskrivning af aktuelle sportive strukturer: Hurtigere, højere, stærkere for der inddrages dans, ekstase og meditation som ikke-resultatorienterede kropskulturformer. Og flere andre aspekter dukker op i horisonten, f.eks.: Hvad med karneval og latterkultur i gammelnordisk idræt?

Det vil selvfølgelig ikke betyde, at: nu sletter vi de gældende kategorier $\mathrm{i}$ nordisk idrætshistorie eller viger udenom: ingen kamp, ingen konkurrence, ingen heroisk mandlighed, ingen krigerisk idræt, men bare shamanisme og hekseri, ekstase og meditation, danse og gøgleri ... Tværtimod! Det gamle

Fig. 9
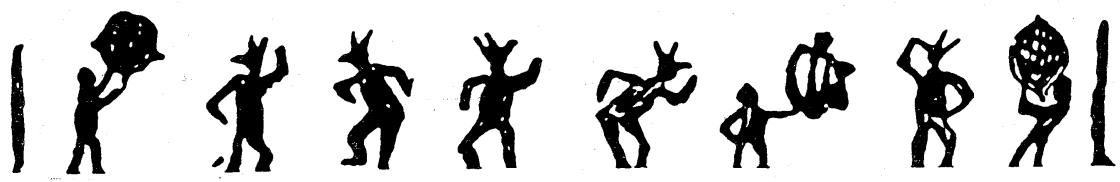

Inuit-tegning: dansere med trommer og dyrehoved. Jørgensen 1981, side 150. 
Fig. 10

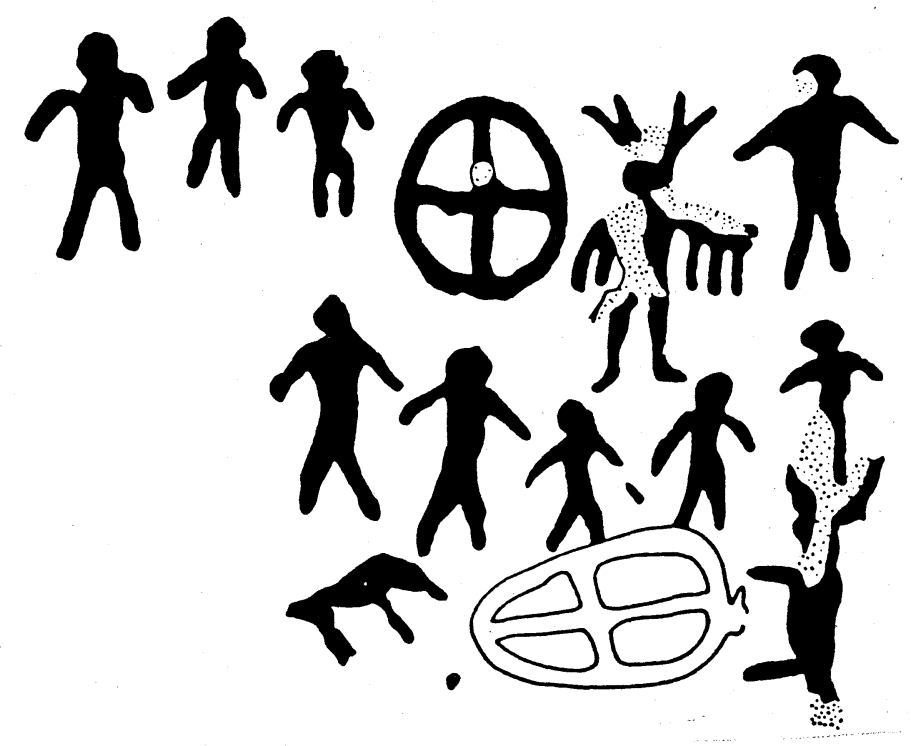

Helleristning fra Altai forestillende en shaman med sin tromme. Gilberg 1978, side 7.

Nordens stærke eller ensidige prioritering af kamp-konkurrence-idræt kan kun forstås, beskrives og diskuteres på en rimelig måde på baggrund af de andre kropskulturelementer og de andre veje, som den nordiske idræt $i k k e$ videreudviklede, men som blev til en slags underjordisk kropshistorie. Hvorfor det?

Det hele bliver altså ikke til en isoleret nyvurdering af idrætshistorien. Men hele det gamle Nordens hverdagsliv kan ses i nyt lys.

Hvor kommer innovationer og paradigmespring fra? Er opdagelser et resultat af nye kilder og forfinede metoder (som positivisten mener) eller af forskernes store ånd (som idealistiske åndshistorikere mener)? Det er samfundsmæssige påvirkninger, som gør sig gældende. Idrætshistorie i en tid, hvor sporten stiger op, ser anderledes ud end $i$ en tid, hvor punkens trommer og breakdance, yogabølgen og tai chi, karneval og gøgleri spiller en rolle. Her kan en levende vekselvirkning finde sted. Det er ikke ensbetydende med at gå med på enhver modebølge, men det betyder, at videnskab forholder sig sensibel over for forandring af samfundet og over for sin egen forandring: det er kroppen, der taler også her.

$\mathrm{Vi}$ skriver historie ikke kun med fyldepen og metoder, ikke kun med tanketraditioner og nye ideer. Vi skriver den med kroppen. 


\section{Litteratur:}

Adamson, Kjell: Dans. I.: Kulturhistorisk leksikon for nordisk middelalder fra vikingetid til reformationstid. København 1957, bd. 2, sp. 651-59.

Bindu. Yoga, Mantra, Meditation. Hellerup, nr. 12, 1974: Runer i Norden (s. 11-14).

Bindu, København, nr. 16, 1976: Kender alle mennesker yoga ..? (s. 2-6, 28-29).

Bjarnason, Bjørn: Nordboernes legemlige uddannelse i oldtiden. København 1905.

Broby-Johansen, R.: Oldnordiske stenbilleder. København 3. opl. 1979.

Brøgger, A. W./Haakon Shetelig (red.): Osebergfundet. Oslo, bd. 2, 1928.

Buchholz, Peter: Schamanistische Züge in der altisländischen Überlieferung. München 1968 (Diss.).

Closs, Alois: Der Schamanismus bei den Indoeuropäern. I: Manfred Mayrhofer o.a. (udg.): Studien zur Sprachwissenschaft und Kulturkunde. Innsbruck 1968, s. 289302.

Davidson, $H$. R. Ellis: Hostile magic in the Icelandic sagas. I: Venetia Newall (udg.): The witch figure. London 1973, s. 20-41.

Diem, Carl: Weltgeschichte des Sports. Bd. 1, Stuttgart, 3. opl. 1971.

Dillmann, François-Xavier: Katla and her distaff: An episode of tri-functional magic in the Eyrbyggja Saga? I: Edgar C. Polomé (udg.): Homage to Georges Dumézil. Washington $1982 \mathrm{~s} .113-24$.

Doht, Renate: Vergleichende Studien zum germanischen Rauschtrankmythos. Wien 1975 (Diss.).

Duerr, Hans Peter: Drömtid. Om gränsen mellan det vilda och det civiliserade. Stockholm 1982.

Duerr, Hans Peter (udg.): Sehnsucht nach dem Ursprung. Zu Mircea Eliade. Frankfurt M. 1983.

Eichberg, Henning: "Intet nyt under solen“? Kamp og drab, yoga og shamanisme i gammel nordisk kropskultur. I: Gerlev Idrætshøjskoles årsskrift 1982, s. 28-35.

Eichberg, Henning: Einheit oder Vielfalt am Ball? Zur Kulturgeschichte des Spiels am Beispiel der Inuit und der Altisländer. I: Ommo Grupe (udg.): Spiel - Spiele Spielen. Schorndorf 1983 s. 131-53.

Engelstoft, Laurids: Om den Priis, Oldtidens Skandinaver satte på Legemsøvelser, mest med hensyn til Nationalopdragelsen. Et Indbydelsesskrift til den offentlige Examen i det Schonboeske Institut. København 1801 (også i Scandinavisk Museum, København 1802 s. 39-82, eftertryk Oslo 1981).

Eriksson, Jörgen I.: Oden som revolutionär. I: Frihetlig Socialistisk Tidskrift Nr. 44 (1982) 18-22.

Fischer, Herbert: Indogermanischer Krigeryoga. I: Festschrift Walter Heinrich. Ein Beitrag zur Ganzheitsforschung. Graz 1963 s. 65-97.

Fleck, Jere: The „knowledge criterion“" in the Grimnismal: The case against ,schamanism". I: Arkiv för nordisk filologi 86 (1971) 49-65.

Fritzner, Johan: Lappernes Hedenskab og Trolddomskunst sammenholdt med andre Folks, især Nordmændenes, Tro og Overtro. I: Historisk Tidsskrift, Kristiania 4 (1877) s. 135-217.

Gilberg, Rolf (red.): Ånder og mennesker. København (Nationalmuseet) 1978.

Gimle, Tidsskrift för shamanism. Stockholm Nr. 5-7, 1982-83.

Götlind, Johan (udg.): Idrott och lek. (= Nordisk Kultur. 24) Stockholm o.a. 1933.

Göttner-Abendroth, Heide: Die tanzende Göttin. Prinzipien einer matriarchalen Ästhetik. München 1982.

Grønbech, Vilhelm: Vor Folkeæt i Oldtiden. Tysk: Kultur und Religion der Germanen. Bd. 2, 4. opl., Hamburg 1939. 
Grüner-Nielsen, H. (udg.): Dans. (= Nordisk Kultur. 24) Stockholm o.a. 1933.

Hartner, Willy: Die Goldhörner von Gallehus. Wiesbaden 1969.

Hauck, Karl: Goldbrakteaten aus Sievern. München 1970.

Hauck, Karl: Brakteatenikonologie. I: Reallexikon der germanischen Altertumskunde. Bd. 3, 2. opl. Berlin 1978, s. 361-401.

Höfler, Otto: Berserker. I: Reallexikon der germanischen Altertumskunde. Bd. 2, 2. opl., Berlin 1976, s. 298-304.

Hölscher, Wilhelm: Die Probleme des historischen Katalogs der Goldgubber. Zulassungsarbeit (utrykt). Münster 1982, del 1.

Holmqvist, Wilhelm: The dancing gods. In: Acta Archaeologica 31 (1960) 101-27.

Jaide, Walter: Das Wesen des Zaubers in den primitiven Kulturen und in den Islandsagas. Borna-Leipzig 1937 (Diss.).

Jørgensen, Ole: Sjæl gør dig smuk. Om Inuit menneskene. Århus 1981.

Kern, Hermann: Labyrinthe. München 1982.

Kuhn, Thomas S.: The structure of scientific revolutions. Chicago 1962.

Lechler, Jörg: Vor 3000 Jahren. Ein frühgermanisches Kulturbild. Erfurt, 2. opl. 1939. Eftertryk Bremen 1981.

Lukas, Gerhard: Die Köperkultur in Deutschland von den Anfängen bis zur Neuzeit. Berlin (DDR) 1969.

Mackeprang, Mogens B.: Om de saakaldte „Guldgubber“. I: Fra Nationalmuseets Arbejdsmark, København 1943, s. 69-76.

Magnusson, Magnus/Werner Forman: Der Hammer des Nordens. Freiburg, 2. opl. 1978.

Matthews, W. H.: Mazes and Labyrinths. London 1922. Eftertryk Detroit 1969.

Mayer, F. Arnold: Ein deutsches Schwerttanzspiel aus Ungarn. I: Zeitschrift für Völkerpsychologie und Sprachwissenschaft 19 (1889) 204-63, 416-33.

Mehl, Erwin: Trojaspiel. I: Realencyclopädie der classischen Altertumswissenschaft. Suppl. 8, Stuttgart 1956, sp. 888-905.

Mehl, Erwin: Der Ausweg aus dem Labyrinth. I: Klaus Beitl (udg.): Volkskunde. Fakten und Analysen. Wien 1972 s. 402-18.

Meschke, Kurt: Schwerttanz und Schwerttanzspiel im germanischen Kulturkreis. Leipzig, Berlin 1931.

Neckel, Gustav: Kultur der alten Germanen. Potsdam 1939.

Nielsen, Kristian Kjær: Odin. I: Rønshoved Højskoles aarsskrift 1983, s. 32-39.

Norlind, Tobias: Svärdsdans och bågdans. I: Festskrift til H. F. Feilberg. Stockholm 1911, s. 738-56.

Oxenstierna, Eric Graf: Die Goldhörner von Gallehus. Lidingö 1956.

Ringbom, Lars-Ivar: Gallehushornens bilder. I: Acta Academiae Aboensis, Humaniora 18 (1949) 258-304.

Saraswati, Swami Janakananda: Yoga, Mantra og Meditation i min hverdag. København 1975.

Schlette, Friedrich: Germanen zwischen Thorsberg und Ravenna. Leipzig o.a. 1972.

Sharp, Cecil J.: The sword-dances of Northern England. 1911. 2. opl., London 1951.

Ström, Folke: Nordisk hedendom. Göteborg 1961.

Strömbäck, Dag: Sejd. Stockholm, København 1935.

Stumpfl, Robert: Kultspiele der Germanen als Ursprung des mittelalterlichen Dramas. Berlin 1936.

Svahn, Ake: Sportliche Motive auf nordischen Felszeichungen und Bildsteinen. Halle 1970 (utrykt diss.).

Thordeman, Bengt (udg.): Vaaben. (= Nordisk Kultur. 12 B). Stockholm o.a. 1943. 
Ueberhorst, Horst: Leibesübungen bei den Germanen. I: Ueberhorst (udg.): Geschichte der Leibesübungen. Bd. 3/1, Berlin 1980, s. 26-46.

Vries, Jan de: Altgermanische Religionsgeschichte. 3. opl. Berlin 1970, Bd. 1-2.

Vries, Jan de: Untersuchungen über das Hüpfspiel. Helsinki, Wiesbaden 1957.

Wahlqvist, Bertil: Barsk idræt. Sport i vikingetiden. Danmark 1979.

Wischmann, Berno/Åke Svahn: Leibesübungen und Sport der Germanen. Hochheim/ M. 1980.

Wolfram, Richard: Schwerttanz und Männerbund. Kassel (1936). 


\section{Søndagen paa Sundet.}

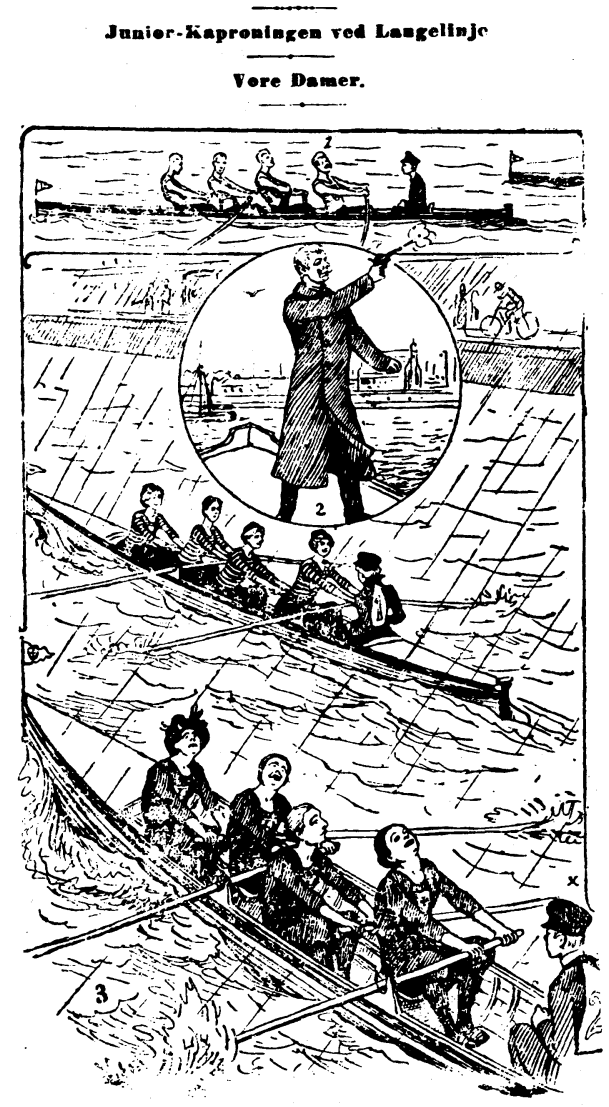

Kvinderoning. Kaproningen ved Langelinie (Pol. 25.9.1905) trak en del tilskuere blandt hvilke „Kvindeløbet vakte ligefrem Sensation“. Når kvinderne roede de $1000 \mathrm{~m}$, styrmændene var i øvrigt mænd, lød bestemmelsen, ,,at Præmien vilde tilfalde det Hold, der roede kønnest, uanset om det var først ved Maalet, naar blot Løbet var fuldent i mindre end 6 Minutter “.

Det viste sig heldigvis, at det hold, der roede hurtigst også roede kønnest således at præmien kunne gå til Damernes Roklub, hvis hold bestod af „,gymnastiklærerinder fra Paul Petersens Kursus“.

Den allestedsværende J. P. Müller (1866-1938), der ses i tegningens midte, var en kendt idrætsmand (atletik og roning) og idrætshygiejniker, der i 1904 blev verdensberømt med bogen „Mit System“, der sidenhen blev oversat til 25 sprog. 